\title{
Together While Apart? \\ Mediating Relationships and Intimacy. An Introduction.
}

\author{
PATRICIA PRIETO-BLANCO, University of Brighton \\ MARIA SCHREIBER, University of Vienna
}

This special issue of Networking Knowledge - Journal of the MeCCSA-PGN seeks to explore how interpersonal relationships are mediated in contemporary contexts. Digital technologies and the practices associated with them enable us to interact with our social network of support in seemingly easy ways: we just need to use the touch of a finger on a mobile phone screen to show that we care. It does, however, also take only the same effort and the same fingertips to enact hate. Acts of disaffection, often crystallized as revenge, originate, in nests and corners of intimacy (Bachelard 1958, p.XXXVII), and when disseminated widely can be fatal ${ }^{1}$. Recently, acts of disaffection, or rather hate, - especially against diffuse, imagined collectives such as "the refugees" - have also appeared in the more public realms of forums, comments sections of online news, or social media feeds. A perception of anonymity might result in 'disinhibition effects' (Suler 2004) and sometimes quite extreme forms of hate speech (Gelber \& McNamara 2016), which poses new challenges for media education and online governance ${ }^{2}$.

Interrogating the pragmatics of mediated affect and disaffection is a necessity. In mediated interpersonal relationships, the intimate and the emotional are often subjected to a set of infrastructures, called affordances by others (Wright and Parchoma, 2011), as well as to set of practices. The contributions that make up Together While Apart? highlight the emotive dimension of mediated communication. The common thread of all contributions to this issue is the focus on how relationships, intimacy, and (dis)affect are constituted and negotiated through media.

The concept of mediation can be described as "a fundamental moment in the development of communication as symbolic interaction: its passing through technologically-based infrastructures of transmission and distribution (“media”)" (Couldry/Hepp 2013: 197). How mediation might also be transforming, moulding, or shaping communication and not only "passing it through" is one of the key questions of media and communication studies. Empirically, this question needs necessarily to be answered through contextual approaches

\footnotetext{
${ }^{1}$ See a recent example "Italian Women commits suicide after sex tape goes viral” Huffington Post, 16. 9. 2016 http://www.huffingtonpost.co.uk/entry/tiziana-cantone-video-italian-woman-commits-suicide-after-sextape-goes-viral_uk_57dbb21fe4b05d79136f23c5

${ }^{2}$ See a recent initiative by the Council of Europe: https://www.nohatespeechmovement.org/
} 
that take cultural, social and technical factors into account. In Media and Communication Studies, affect and intimacy have started to gain more relevance as research areas in their own right.

Significant inquiries into contemporary mediations and the everyday have been carried out by feminist scholars (Fortunati and Taipale, 2012; Hjorth and Lim, 2012; Rose, 2012). Their investigations show the necessity of thinking beyond the dichotomy of public and private when exploring contemporary contexts, processes, and experiences. New media enable the emergence and management of various kinds of networked and imagined (boyd 2011), ambient, and intimate (Hjorth et al. 2012) publics. It is necessary to understand practices of differentiation in regard to what is made visible to whom, who is included and excluded in which publics, and how media structures are an intrinsic part of these practices. 'Privacy' is not a fixed entity; it is always practiced in relation to 'publicness,' and has to be understood as transforming in relation to publics and media (Wagner 2014, p. 124). Today, perhaps more than ever, the personal is political.

Current constellations of people and their mediations navigate between social realms, and the cracks opened by their flow requires an interdisciplinary approach, arguably implemented by default by feminist and queer theory scholars. In Media Studies, a focus on practices over the past ten years has shed some light upon everyday mediations and mediations of the everyday (Postill 2010; Couldry \& Hepp 2013; Lehmuskallio \& GomezCruz 2016). Lines of inquiry centered on media practices are often about a sense -- a feeling -- that is personal and intersubjective, as well as specific, and that is in constant interplay with the technological conditions in which it arises.

Though the way we communicate with each other, and the way that media co-constitute our relationships, have lately undergone definitive transformations, interpersonal communication has a sustained genealogy of various material and technical mediations (Milne 2010). With digital technologies, convergence, and social media platforms, and through the resulting ubiquity and mobility of devices such as smartphones, the possibilities of mediating relationships have expanded and been transformed. Recent empirical research has identified further theoretical access points. Take, for example, Madianou's study on migrant mothers and their mediated communicative interactions with their children back home. Hers is an important contribution to a relational understanding of new media as 'polymedia': "as an 'integrated structure' within which each individual medium or platform is defined in relational terms in the context of all other media. In conditions of polymedia, our emphasis shifts from a focus on the qualities of each particular medium as a discrete technology, to an understanding of new media as an environment of affordances." (Madianou 2014, p. 670). The contributions in this journal explore how specific constellations of relationships and media play out in cultural contexts. On one hand, this collection highlights the need to understand the social relations, or conditions of 
sociability/socialization, underlying patterns and rules or habits of interaction. On the other hand, media pragmatics also attend to specific techno-material rules and structures. Our aim is to understand these intersections of intimacy, sociality, and digital media. How do affordances of mediation relate to practices of the everyday and social life(s) in contemporary times?

By featuring theoretical propositions alongside empirical studies on mediations of everyday life, Together While Apart highlights how mediated interactions are nowadays entangled with emotional processes of socialization and practices of connectivity. The contributions integrate traditional approaches, such as ethnography, with innovative methods, such as the visual essay. In their narratives there is an awareness of the temporal and the procedural in emotional communication. From apps, to internet cafes, and monthsaries, the case studies of this issue explore how users manage constellations of emotions, relationships and mediations.

The importance of different kinds of relationship- and individuation processes transforms and changes throughout the course of life, and so does the mediation of these practices. Normative imaginations of who and how one should be as child, teen, young adult, or adult come into play in relation to biographical experiences and developmental tasks (PausHasebrink 2010). We are happy to feature contributions that take these relationalities into account in regard to very different life stages, from childhood (Frolova), to young adulthood (Siilas), and young coupling (Abidin), to adulthood (Lee). These contributions also feature research from a broad variety of cultural contexts: parenting in Britain, backpacking Westerners in South-East-Asia, young coupling in Singapore, Transexperience in the US, the globally available app and video format Vine, and of course the globally known heart-symbol, which French people apparently dislike.

\section{The Collection}

The collection of articles that make Together While Apart explores contemporary mediations of interpersonal and (dis)affective relationships. Within the variety of contexts analysed in this issue, the themes of the digital ephemeral and ubiquitous mediations of the everyday resonate consistently and thoroughly. Intersections of privacies and publics are examined alongside strategies of resistance, from attempts to archive the ephemeral throughout the life course of relationships, to efforts to mediate everyday presence.

How deep is your love? At the heart of Carolina Cambre's contribution is one of the bestknown and most-used emojis, the heart-symbol. In the form of a visual essay with accompanying text, she discusses and shows various aspects of the little red sign: historical iconographies, cultural contexts, and complex entanglements with the politics of affect. 
Contemporary relationships of affinity and (dis)affect are strongly based on actions, rather than on norms and rules (Plummer, 2003). Interpersonal connections are endlessly reworked by members of networks of social support (Gabb, 2008). The mediation of everyday moments can thus be interpreted as a mechanism of affection and intimacy disclosure (Jamieson, 1998). Recent empirical research has revealed how mechanisms of (dis)affect, such as sending photographs via Whatsapp, a) connect individuals, b) evidence pro-active behaviour, and c) give rise to places of (dis)affect (Prieto-Blanco, 2016). Contemporary places of (dis)affect are digitally, both figuratively and literally, stretched. They might also be users' third places in Ray Oldenburg's sense, namely an environment that enables them to focus on experiences and relationships informally, allowing for social, perhaps even intimate, interactions to take place (1989, p. 23). As Everiin Silas (in this issue) suggests, non-places become spaces for mediated communication: "to calm worried parents, make travel arrangements and cure their travel-time loneliness”.

Accessing and using various kinds of media is generally perceived as an important developmental task, and a significant amount of research focuses on potential dangers that media use might engender for children. The role of parents in enabling or restricting access is an ever discussed topic. In her article, Ksenia Frolova focuses on potential factors that motivate parents to encourage media use in younger children. A striking finding of her work is the added value convergent digital media devices provide as easy-to-use audiovisual interpersonal communication tools. Devices such as tablets, for example, allow even very young children to Skype with their grandparents no matter where they are. Parenting in its remote form remains an important practice also later on in life, as Everiin Silas points out. In her study of the smartphone's role in contemporary backpacking practices, she states that what changes with growing up is not only owning a device, but also being in control over when and where to go online and connect; as well as to decide and curate what kind of connectivity one wants to establish with friends and family back home. Not having connectivity at all, but "being offline" to improve the immersion into the experience of being abroad and embedded in another culture, is another decision that some of Silas' respondents have taken.

Moving on to another stage in the course of life, that of young coupling, Crystal Abidin discusses the ambivalence and arbitrary importance of a romantic ritual, the monthsary, in a Singaporean context. She identifies vernacular meanings through internet folklore and enactments of this ritual by microcelebrity couples, as well as affirmation and backlash towards these practices. While monthsaries are a widely accepted and heteronormative practice, Jamie Lee's contribution deals with a more contested issue of discrimination. Her work explores complex and often discriminated-against processes of becoming: "What kind of transgender are you?", is the question posed to interviewees for the Arizona Queer Archives. The overlap of an intimate interview situation and the publicly available archive are discussed in relation to different perceptions of what being trans can actually mean. 
Lee's contribution already foregrounds how the moulding force of the camera frames and constitutes the specific interview situation.

Filming is also a central element in Elke Rentemeister's article on the ultra-short video format and app 'Vine', which has recently been shut down. She analyses how para-social interactions and intimacy are performed in specific Vine series, and how the format coconstitutes specific forms of narrations and performing authenticity. Through the work of Lee and Rentemeister, specific forms of mediations and the role software, symbols, and algorithms might play, are addressed.

In our view, visual media are of particular relevance in practices of affective communication (Prieto-Blanco \& Schreiber forthcoming). They enhance communication in a sense that they add a specific visual way of expressing meaning that goes beyond that which can be expressed in terms of language (Burri 2012; Schreiber 2016). Cameras and digital displays populate domestic settings around the world, allowing individuals to visually mediate their everyday lives in ways that were unimaginable only a few decades ago. Something can be shown and made visible - therefore, visual media may afford the emergence of shared spaces of (social) co-presence and ambient intimacy (Prieto-Blanco, 2010; 2016). This becomes relevant in the contributions of strategic performance of couples on instagram (Abidin), ultrashort videos (Rentemeister), oral history interviews with transgender people (Lee), and the complex meaning- and affection-making of the heart symbol (Cambre). Networked cameras and networked images (Lehmuskallio \& GómezCruz 2016) have strongly affected contemporary practices of mediation and the interpersonal relations thereby mediated. Contemporary mediations attend to constellations of polymedia (Madianou 2014) as well as processes of remediation (Grusin \& Bolter 2000) and convergence (Jenkins 2004). This context allows users to activate affordances in the service of (dis)affect and intimacy.

Finally, on a non-theoretical and more personal note, we would like to take the opportunity and express our own affect and gratitude via this very specific medium of academic publications: We would like to thank all the reviewers for their time and effort, their inputs and criticism were essential to this issue!

\section{References}

Bachelard, G. (1958) The Poetics of Space. The classic look at how we experience intimate places. Boston: Beacon Press.

Boyd, D. (2011) 'Social Network Sites as Networked Publics'. In Z. Papacharissi (ed) A Networked Self. Identity, Community, and Culture on Social Network Sites, New York: Routledge, pp. 39-58 
Burri, R. V., (2012) 'Visual rationalities: Towards a sociology of images', Current Sociology, 60 (1), 45-60

Couldry, N. and Hepp, A. (2013) 'Conceptualizing Mediatization: Contexts, Traditions, Arguments', Communication Theory 23 (3), 191-202

Fortunati, L. and Taipale, S. (2012) 'Women's emotions towards the Mobile Phone', Feminist Media Studies, 12 (4), 538-549

Gabb, J. (2008) Researching Intimacy in Families, London: Palgrave MacMillan

Gelber, K., and McNamara, L. (2016) 'Evidencing the harms of hate speech.' Social Identities, 22(3), 324-341

Grusin, R. and Bolter, J. (2000) Remediation. Understanding New Media, Cambridge and London: The MIT Press.

Hjorth, L., and Lim, S. (2012) 'Mobile intimacy in an age of affective mobile media', Feminist Media Studies, 12(4), 477-484

Hjorth, L., Wilken, R. and Gu, K. (2012) 'Ambient Intimacy. A Case Study of the iPhone, Presence and Location-based Social Media in Shanghai, China', in L. Hjorth, J. Burgess, \& I. Richardson (eds), Studying mobile media: cultural technologies, mobile communication, and the iPhone. pp. 43-62

Jamieson, L. (1998) Intimacy. Personal Relationships in Modern Societies, Maldon: Polity Press.

Jenkins, H. (2004) 'The Cultural Logic of Media Convergence', International Journal of Cultural Studies, 7(1), 33-43

Larsen, J. (2004) The Life of Digital Photographs: The Case of Tourist Photography. Ph. D. Roskilde University.

Lehmuskallio, A. and Gómez-Cruz, E. (2016) 'Why Material Visual Practices?' in E. Gómez Cruz and A. Lehmuskallio (eds), Digital Photography and Everyday Life. Empirical Studies on Material Visual Practices, London: Routledge, pp. 1-16

Madianou, M. (2014) 'Smartphones as Polymedia', Journal of Computer-Mediated Communication, 19(3), 667-680

Milne, E. (2010) Letters, postcards, email: Technologies of presence. New York: Routledge.

Oldenburg, R. (1989) The Great Good Place: Cafes, Coffee Shops, Community Centers, Beauty Parlors, General Stores, Bars, Hangouts, and How They Get You Through the Day. New York: Paragon House.

Paus-Hasebrink, I. (2010) 'Lebens-Herausforderungen. Medienumgang und Lebensaufgaben. Was muss kommunikationswissenschaftliche Forschung leisten?' in M. Hartmann and A. Hepp (eds) Die Mediatisierung der Alltagswelt. pp. 195-209.

Plummer, K. (2003) Intimate Citizenship: Private Decisions and Public Dialogue, Washington: University of Washington Press.

Prieto-Blanco, P. (2010) 'Family Photography as a phatic construction', Networking Knowledge: Journal of the MeCCSA Postgraduate Network, 3(2). 
Prieto-Blanco, Patricia (2016) Transnational (Dis) Affect in the Digital Age. Photographic Practices of Irish - Spanish Families Living in Ireland. National University of Ireland, Galway.

Rose, G. (2012) Doing Family Photography. The Domestic, the Public and the Politics of Sentiment. Ashgate: Farnham.

Schreiber, Maria. 2016. "Amplification and Heterogeneity: Seniors and Digital Photographic Practices." In E. Gómez Cruz and A. Lehmuskallio (eds), Digital Photography and Everyday Life. Empirical Studies on Material Visual Practices, London: Routledge. pp . 52-69

Suler, J. (2004) 'The Online Disinhibition Effect' CyberPsychology \& Behavior. July 2004, 7(3): 321-326

Wagner, E. (2014) 'Intimate Publics 2.0. Zur Transformation des Privaten und des Öffentlichen in Social Network Sites. In K. Hahn (ed), E.Motion. Intimität in Medienkulturen. Wiesbaden: Springer VS, pp. 125-150

Wright, S. and Parchoma, G. (2011) 'Technologies for learning? An actor-network theory critique of 'affordances' in research on mobile learning', Research in Learning Technology, 19: 3, 247-258

Patricia Prieto-Blanco lectures photography at the University of Brighton, UK. Her area of expertise are visual methods of research and reception studies. She is an advocate of interdisciplinary, participatory and practice-based research, as well as a proud member of HYSTERIA radical feminist collective.

Email: P.PrietoBlanco@brighton.ac.uk

Maria Schreiber is a PhD candidate at the Department of Communication, University of Vienna, holding a scholarship of the Austrian Academy of Science as part of the interdisciplinary DOC-team 'Pictorial Practices' (http://bildpraktiken.wordpress.com). She is currently finishing her dissertation project on age-specific photo sharing practices.

Email: maria.schreiber@univie.ac.at 